\title{
Evaluation of New Oomycota Fungicides for Management of Phytophthora Root Rot of Citrus in California
}

\author{
Wei Hao, Morgan A. Gray, Helga Förster, and James E. Adaskaveg ${ }^{\dagger}$ \\ Department of Microbiology and Plant Pathology, University of California, Riverside, CA
}

\begin{abstract}
Phytophthora root rot, caused by several species of Phytophthora, is an important disease of citrus in California and other growing regions. For chemical management, mefenoxam and potassium phosphite have been available for many years, and resistance in Phytophthora spp. has been reported for both compounds. We evaluated the efficacy of the new Oomycota fungicides ethaboxam, fluopicolide, mandipropamid, and oxathiapiprolin, each with a different mode of action, against Phytophthora root rot of citrus in field and greenhouse studies. Root balls of navel orange trees on 'Carrizo citrange' rootstock were inoculated with $P$. nicotianae at planting in the field in fall 2013. Applications with 11 fungicide treatments were made 5 weeks after planting, in spring and fall 2014, and in spring 2015. Feeder roots and adjacent soil were collected before or after application. All of the new fungicides significantly reduced root rot incidence and Phytophthora soil populations to very low levels as compared with the control starting after the first

application. Mefenoxam was only effective when a high label rate was used in the fourth application. Selected treatments also increased tree canopy size, trunk diameter, and fruit yield as compared with the control. A rate comparison with the four new fungicides was initiated in summer 2016 in another field trial using navel orange trees inoculated with $P$. citrophthora. Minimum effective rates to reduce Phytophthora root rot incidence and pathogen soil populations were determined after one and two applications in fall 2016 and summer 2017, respectively. Greenhouse studies confirmed the efficacy of the new fungicides. Based in part on our studies, fluopicolide recently received a federal and oxathiapiprolin a full registration for use on citrus, and registrations for ethaboxam and mandipropamid have been requested. These new compounds will provide highly effective treatment options and resistance management strategies using rotation and mixture programs for the control of Phytophthora root rot of citrus.
\end{abstract}

Phytophthora root rot is one of most destructive diseases of citrus and occurs worldwide (Erwin and Ribeiro 1996). Symptoms begin with a brown discoloration and dieback of feeder roots. If the damage of feeder roots exceeds their regeneration, adequate water and nutrient uptake will be impeded, resulting in a slow decline of the tree. The disease can be caused by several soilborne Phytophthora species, including Phytophthora citrophthora (R.E. Sm. \& E.H. Sm.) Leonian and $P$. nicotianae Breda de Haan (syn. P. parasitica Dastur) as well as $P$. cactorum (Lebert \& Cohn) J. Schröt., P. drechsleri Tucker, $P$. megasperma Drechsler, and P. palmivora (E.J. Butler) E.J. Butler (Erwin and Ribeiro 1996). In California, P. nicotianae and $P$. citrophthora are the major causal pathogens of Phytophthora root rot of citrus, and these species can also infect citrus fruit and tree trunks, causing brown rot and gummosis, respectively. P. nicotianae is most active during the warmer months, whereas $P$. citrophthora can be recovered year-round (Hao et al. 2016).

Management of Phytophthora root rot is especially critical in the first few years of a new citrus planting during orchard establishment. Additionally in California, all Phytophthora diseases of citrus, including root rot, brown rot, and gummosis, are subject to intense management due to recent export restrictions to China that were imposed after the detection of orange fruit with brown rot caused by $P$. syringae (Kleb.) Kleb. and $P$. hibernalis Carne that are quarantine pathogens in this country (Förster et al. 2016). Phytophthora root rot management requires an integration of rootstock selection, cultural practices, and fungicide applications. Phytophthora-tolerant rootstocks such as Trifoliate and Trifoliate hybrids (e.g., C-35 and

${ }^{\dagger}$ Corresponding author: J. E. Adaskaveg; E-mail: jim.adaskaveg@ucr.edu

Funding: This work was supported by a grant from the Citrus Research Board (CRB) Project no. 5600-103.

Accepted for publication 4 September 2018.

() 2019 The American Phytopathological Society
Swingle) can be used for grafting commercially acceptable citrus scions (Ferguson et al. 1990; Roose 2014). Irrigation and orchard management strategies that reduce over-watering will render the soil environment less favorable for infection by the motile zoospores, the main infective propagules of Phytophthora spp.

Two fungicide modes of action (i.e., FRAC codes; FRAC 2018) were used extensively for many years as the sole chemical treatments for the management of Phytophthora root rot of citrus, the phenylamides (e.g., metalaxyl, mefenoxam; FRAC code 4) and phosphonates (e.g., fosetyl-Al, potassium phosphite; FRAC code 33). Resistance to the phenylamides has been reported in populations of several species of Phytophthora since the 1980 s, including $P$. citricola, $P$. cryptogea, $P$. infestans, $P$. megasperma, and $P$. nicotianae (Davidse et al. 1981; Ferrin and Kabashima 1991; Gisi and Cohen 1996; Hwang and Benson 2005; Stack and Millar 1985). On citrus, resistant $P$. nicotianae isolates were identified in over half of the citrus nurseries sampled in Florida (Timmer et al. 1998). Phosphonate resistance has developed less frequently. Isolates of $P$. capsici, $P$. cinnamomi, and $P$. infestans with reduced sensitivity have been reported (Cohen and Samoucha 1984; Veena et al. 2010; Wilkinson et al. 2001). We recently determined that $10-20 \%$ of isolates of $P$. syringae and $P$. citrophthora from California citrus orchards were less sensitive to potassium phosphite in vitro. Brown rot caused by these isolates could not be controlled using registered rates of potassium phosphite in field applications, and postharvest treatments with this chemical were significantly less effective than when fruit were inoculated with a sensitive isolate (Adaskaveg et al. 2017; Förster et al. 2016).

To manage Phytophthora diseases of citrus and prevent further resistance development to phenylamide and phosphonate fungicides, new effective Oomycota fungicides need to be identified. Four new compounds have recently become available for evaluation on citrus, each with a different mode of action that is also different from fungicides currently available for citrus. They have been registered in the United States for some time for the management of various foliar and soil-borne diseases caused by Oomycota pathogens on selected crops where they proved to be highly efficacious (Bittner and Mila 2016; Cortright et al. 2016; Jackson et al. 2010; Ji et al. 2014; Patel 
et al. 2015), and their biochemical modes of action have been identified. The thiazole carboxamide (FRAC code 22) ethaboxam inhibits mitosis and cell division (Uchida et al. 2005), the benzamide (FRAC code 43) fluopicolide destabilizes plasma membrane formation by delocalizing a spectrin-like protein (Toquin et al. 2006), the carboxylic acid amide (FRAC code 40) mandipropamid targets the cellulose synthase-like gene and inhibits pathogen cell wall synthesis (Blum et al. 2010), and oxathiapiprolin, the first fungicide in the isoxazoline class (FRAC code 49), inhibits an oxysterol binding protein and thereby inhibits many cellular processes (Pasteris et al. 2016). We previously determined that the four fungicides were highly inhibitory to mycelial growth of $P$. nicotianae, $P$. citrophthora, $P$. syringae, and $P$. hibernalis isolates from citrus in California (Gray et al. 2018). Furthermore, oxathiapiprolin and mandipropamid also inhibited sporangium and oospore formation as well as zoospore cyst germination using low concentrations, and oxathiapiprolin was also highly active against chlamydospore formation (Gray et al. 2018).

The objective of this study was to evaluate the efficacy of ethaboxam, fluopicolide, mandipropamid, and oxathiapiprolin against citrus root rot under field and greenhouse conditions using citrus trees or seedlings inoculated with $P$. nicotianae or $P$. citrophthora. For this, we determined the effects on soil population sizes of the pathogens, incidence of root infections, and we measured tree growth parameters including tree canopy size, trunk diameter, and fruit yield.

\section{Materials and Methods}

Field studies with navel orange trees inoculated with P. nicotianae. A field trial was established in September 2013 with 3-year-old 'Fukumoto' navel orange (Citrus sinensis (L.) Osbeck) trees grafted on 'Carrizo citrange' rootstock. The field with a fine sandy loam was located at the field station of the University of California, Riverside (UCR Agricultural Operations). Twelve trees were planted in each of 28 rows with spacing between rows of $6.4 \mathrm{~m}$ and between trees in a row of $2.9 \mathrm{~m}$. Trees were planted within basins and were irrigated with a bubbler emitter for every tree. Trees were protected by trunk guards to prevent sunburn and rabbit damage. Pest and weed control, as well as fertilization, were performed according to standard agricultural practices for citrus.

Trees were inoculated with chlamydospores of $P$. nicotianae (isolate 2390, Table 1) at planting. For this, four 9-mm-diameter plugs from 10-day-old cultures on 10\% clarified V8 (V8C) agar (Ribeiro et al. 1978) were transferred to $20 \mathrm{ml}$ of $10 \%$ V8C broth in $10-\mathrm{cm}$ petri dishes and incubated at $20^{\circ} \mathrm{C}$ in the dark for 6 weeks. Mycelial mats with chlamydospores were blended using a PowerGen 700 homogenizer (Fisher Scientific Inc., Pittsburgh, PA) equipped with a 32-mm-diameter generator probe at speed setting 1 for $1 \mathrm{~min}$. The suspension was adjusted to $3.4 \times 10^{5}$ chlamydospores $/ \mathrm{ml}$ with sterile deionized water (SDW), and $50 \mathrm{ml}$ was evenly dispensed over the root ball of each tree at planting. Based on the average volume of a root ball with adhering soil of 3 liters, approximately 15 chlamydospores per gram of soil were used as inoculum, which is the threshold of causing severe Phytophthora root rot of citrus (Lutz and Menge 1986).

A randomized complete block design with seven four-tree replications was used for each treatment. The first fungicide application was conducted 5 weeks after inoculation in October 2013. Additional applications were done during feeder root flushes in June and
September 2014, and May 2015. Ethaboxam (Intego; Valent USA, Walnut Creek, CA), fluopicolide (Presidio; Valent USA), mandipropamid (Revus; Syngenta Crop Protection, Greensboro, NC), oxathiapiprolin (Orondis; Syngenta Crop Protection), mefenoxam (Ridomil Gold SL; Syngenta Crop Protection), and selected mixtures were applied at rates indicated in Table 2 with a total of 11 treatments. Fungicide solutions $(500 \mathrm{ml})$ were applied as soil drenches to the basin of each tree. Trees were then irrigated for $1 \mathrm{~h}$ to move the chemicals into the root zone. Trees treated with water were used as controls.

Field studies with navel orange trees inoculated with P. citrophthora. A field trial was initiated in June 2016 at UCR Agricultural Operations to evaluate effective application rates of the new fungicides. Ten 1-year-old 'Fisher' navel orange trees, grafted on Carrizo citrange rootstock, were planted in each of 12 rows. Between-row spacing was $6.4 \mathrm{~m}$ and within-row spacing was $3.5 \mathrm{~m}$. Growing conditions and agricultural practices were the same as in the first field trial.

Trees were inoculated in July 2016 (3 weeks after planting) and October 2016. $P$. citrophthora-colonized vermiculite-oat seed inoculum was prepared as described by Matheron and Mircetich (1985) with minor modifications. In brief, a volume ratio of 2:4:3 of oat seeds, vermiculite, and 10\% regular V8 broth (Miller 1955) was mixed, $600 \mathrm{ml}$ of the mixture was filled into 1-liter plastic containers, and containers were autoclaved for $45 \mathrm{~min}$ each on four consecutive days. Each container was inoculated with $1010 \%$ V8C agar plugs of $P$. citrophthora cultures (isolates 5475 or 5476 , Table 1), mixed by shaking, and incubated at $25^{\circ} \mathrm{C}$ for $4-6$ weeks with weekly shaking and mixing of the contents. Inoculum of the two isolates was mixed in a 1:1 ratio, and $25 \mathrm{ml}$ was buried $10 \mathrm{~cm}$ deep at each of two locations at the base of each tree around the root ball.

A randomized complete block design with six single-tree replications was used for each treatment. Fungicides were applied in July 2016 ( 2 weeks after inoculation) and in May 2017. Fungicides and rates used are listed in Table 2, and fungicides were applied as described above. Plants treated with water were used as controls.

Disease assessments. Phytophthora root rot incidence and Phytophthora propagule populations in rhizosphere soil were evaluated to assess the efficacy of treatments. In the $P$. nicotianae trial, feeder roots and rhizosphere soil $(0.3-0.5 \mathrm{~kg}$ per tree) were sampled in early June and early September 2014 before the second and third fungicide applications, respectively, and in late June 2015 after the last application. Samples were taken from the middle two trees of each fourtree replication and were combined. In the $P$. citrophthora trial, roots and soil were sampled in December 2016 and July 2017 from each tree. Samples were collected at the dripline of each tree at a depth of $\leq 20 \mathrm{~cm}$, placed in plastic bags, and processed the same day.

Feeder roots were carefully separated from soil, rinsed three times with deionized water, and dried on paper towels. Roots were cut into $1-\mathrm{cm}$-long sections using a sterilized razor blade, and 20 pieces were plated onto each of two plates of selective Phytophthora isolation medium (PARHFB-V8C; Ferguson and Jeffers 1999; Hao et al. 2018). When present, root pieces with visible lesions were selected. Plates were incubated at $25^{\circ} \mathrm{C}$ in the dark for 2-3 days. $P$. nicotianae colonies were identified by their typical growth pattern (Erwin and Ribeiro 1996), and representative colonies were subcultured and verified for species identity using species-specific TaqMan qPCR (Hao et al. 2018). Phytophthora

Table 1. Information on Phytophthora nicotianae and P. citrophthora isolates used to inoculate citrus plants in field and greenhouse studies

\begin{tabular}{|c|c|c|c|c|c|c|c|c|c|c|}
\hline \multirow[b]{2}{*}{ Species } & \multirow[b]{2}{*}{ Isolate ID } & \multirow[b]{2}{*}{ Origin } & \multirow[b]{2}{*}{ Year } & \multirow[b]{2}{*}{ Source } & \multicolumn{6}{|c|}{$\mathbf{E C}_{50}$ values for mycelial growth inhibition $(\mu \mathrm{g} / \mathrm{ml})^{y}$} \\
\hline & & & & & $\begin{array}{l}\text { Etha- } \\
\text { boxam }\end{array}$ & Fluopicolide & Mandipropamid & Oxathiapiprolin & Mefenoxam & $\begin{array}{c}\text { Potassium } \\
\text { phosphite }\end{array}$ \\
\hline P. nicotianae & $2390^{z}$ & Tulare, CA & 2001 & Rhizosphere & 0.003 & 0.095 & 0.005 & 0.0006 & 0.232 & 49.12 \\
\hline P. citrophthora & $2440^{z}$ & Ventura, CA & NA & Rhizosphere & 0.049 & 0.048 & 0.004 & 0.0015 & 0.091 & 7.58 \\
\hline P. citrophthora & 5475 & Riverside, CA & 2015 & Rhizosphere & 0.090 & 0.037 & 0.005 & 0.0004 & 0.053 & 6.17 \\
\hline P. citrophthora & 5476 & Riverside, CA & 2015 & Rhizosphere & 0.093 & 0.037 & 0.004 & 0.0005 & 0.061 & 6.23 \\
\hline
\end{tabular}

${ }^{y}$ Effective concentrations ( $\mathrm{EC}_{50}$ values) of fungicides to inhibit mycelial growth by $50 \%$ for ethaboxam, fluopicolide, mandipropamid, oxathiapiprolin, and mefenoxam was determined using the spiral gradient dilution method; whereas the agar dilution method was used for potassium phosphite.

${ }^{\mathrm{z}} \mathrm{EC}_{50}$ values for ethaboxam, fluopicolide, mandipropamid, oxathiapiprolin, and mefenoxam were reported in Gray et al. (2018). 
root rot incidence was calculated as the percentage of infected root pieces of 20 pieces plated per plate.

Rhizosphere soil was mixed well, and for every treatment replicate, a 10-g aliquot was mixed with $90 \mathrm{ml}$ SDW in a 250-ml flask containing three stainless steel beads ( $6 \mathrm{~mm}$ diameter) on a rotary shaker (G24 Environmental Incubator Shaker, New Brunswick Scientific, Edison, NJ) at $150 \mathrm{rpm}$ for $40 \mathrm{~min}$. Aliquots of $1 \mathrm{ml}$ soil suspension were plated on triplicate plates of PARHFB-V8C medium using a sterilized glass spreader. Plates were rinsed with deionized water after $24 \mathrm{~h}$ at $25^{\circ} \mathrm{C}$ in the dark to remove excess soil, and then further incubated for 1-2 days. The number of $P$. nicotianae colonies on each plate was assessed, and propagule populations in the rhizosphere were calculated as CFU per gram of soil.

Tree growth measurements. Tree trunk diameter, canopy size, and fruit production were determined to further evaluate the effectiveness of fungicide treatments in the first field trial. Trunk diameter of every tree at $10 \mathrm{~cm}$ above the graft union was measured in February, July, and December 2015 using a caliper. Tree canopy size was measured in April 2015 and 2016 for one representative tree with a visually average canopy size for the four trees per replication (preferentially one of the two middle trees). For this, a digital image of each entire canopy was obtained with a blue tarp $(2.44 \times 2.44 \mathrm{~m})$ as background. Pictures were taken at approximately the same distance $(5.4 \mathrm{~m})$ from each tree, and the tarp was also kept at the same distance. This was done under overcast conditions to minimize shadow effects on tree canopy estimation. Images were analyzed using Assess 1.0: Image Analysis Software for Plant Disease Quantification (American Phytopathological Society, St. Paul, MN) to calculate the two-dimensional tree canopy. The percentage of tree canopy area in the blue tarp area was computed by defining the two areas by their distinct colors (green versus blue) in the software, and the canopy area of each tree (in $\mathrm{m}^{2}$ ) was calculated based on the tarp area of $5.96 \mathrm{~m}^{2}$. Mature, commercial-grade orange fruit were harvested in December 2016 and 2017, and the number and weight of fruit per tree were determined.

Greenhouse studies with inoculated citrus plants. 'Madam Vinous' sweet orange that is considered susceptible to Phytophthora root rot was used in these studies. Plants were grown from seed in 1-liter pots in UC-C soil mix (Matkin and Chandler 1957) at $18-35^{\circ} \mathrm{C}$ in the greenhouse, watered using micro drippers, and fertilized with Osmocote 14-14-14 Slow Release Fertilizer (Scotts, Marysville, $\mathrm{OH}$ ) once at transplanting. Six- to nine-month-old plants were inoculated with a chlamydospore suspension of $P$. nicotianae (isolate 2390, Table 1) that was produced as described above. One milliliter suspension (3,000 chlamydospores $/ \mathrm{ml}$ ) was added into each of four holes ( $3 \mathrm{~cm}$ deep, $7 \mathrm{~mm}$ diameter) around each plant resulting in an equivalent of approximately 20 chlamydospores/g soil.

Treatments were applied 1 week after inoculation. For potassium phosphite, ProPhyt (Helena Chemical Co., Collierville, TN) was used. Greenhouse application rates (Table 2) were proportionally reduced from the respective field rates based on the ratio of the average surface of tree basins in the field to the soil surface of a potted plant (i.e., a 25:1 ratio). A randomized complete block design with four single-pot replications was used for each treatment. Fungicides were applied as aqueous suspensions (50 ml/plant) to the soil around each plant. Plants treated with $50 \mathrm{ml}$ of water were used as controls.

The effectiveness of fungicides was evaluated after 6-7 months. For each plant, the root ball with soil was carefully removed from the pot. Soil adjacent to roots was collected, and root balls were

Table 2. Fungicide treatments evaluated to manage Phytophthora root rot of navel orange under field and greenhouse conditions

\begin{tabular}{|c|c|c|c|c|c|c|c|}
\hline \multirow[b]{3}{*}{ Treatment } & \multicolumn{4}{|c|}{ Field studies } & \multicolumn{3}{|c|}{ Greenhouse studies } \\
\hline & \multicolumn{2}{|c|}{ Rate } & \multirow{2}{*}{$\begin{array}{c}\text { P. nicotianae } \\
\text { study }\end{array}$} & \multirow{2}{*}{$\begin{array}{l}P \text { P. citrophthora } \\
\text { study }\end{array}$} & \multirow[b]{2}{*}{ Rate $(\mathrm{mg} / \text { pot })^{\mathrm{u}}$} & \multirow{2}{*}{$\begin{array}{c}P . \text { nicotianae } \\
\text { study }\end{array}$} & \multirow{2}{*}{$\begin{array}{c}\text { P. citrophthora } \\
\text { study }\end{array}$} \\
\hline & g/ha & $\mathrm{g} /$ tree $^{\mathrm{u}}$ & & & & & \\
\hline \multirow[t]{4}{*}{ Mefenoxam } & 246 & 0.71 & $\mathrm{X}^{\mathrm{v}, \mathrm{w}}$ & $-^{\mathrm{v}}$ & - & - & - \\
\hline & 561 & 1.62 & $\mathrm{X}^{\mathrm{w}}$ & - & 67 & - & $\mathrm{X}$ \\
\hline & 1,122 & 3.24 & - & - & 134 & $\mathrm{X}$ & - \\
\hline & 2,245 & 6.48 & $X^{\mathrm{w}}$ & - & - & - & - \\
\hline \multirow[t]{6}{*}{ Ethaboxam } & 18 & 0.05 & - & $X$ & - & - & - \\
\hline & 35 & 0.10 & - & $\mathrm{X}$ & - & - & - \\
\hline & 70 & 0.20 & - & $\mathrm{X}$ & - & - & - \\
\hline & 140 & 0.41 & - & $\mathrm{X}$ & - & - & - \\
\hline & 351 & 1.01 & $\mathrm{X}$ & - & 41 & $\mathrm{X}$ & $\mathrm{X}$ \\
\hline & 702 & 2.03 & - & - & 81 & $\mathrm{X}$ & - \\
\hline \multirow[t]{5}{*}{ Fluopicolide } & 35 & 0.10 & - & $\mathrm{X}$ & - & - & - \\
\hline & 70 & 0.20 & - & $\mathrm{X}$ & - & - & - \\
\hline & 140 & 0.41 & $\mathrm{X}$ & $\mathrm{X}$ & 14 & $\mathrm{X}$ & $\mathrm{X}$ \\
\hline & 210 & 0.61 & $\mathrm{X}$ & - & 24 & $\mathrm{X}$ & - \\
\hline & 281 & 0.81 & - & $\mathrm{X}$ & - & - & - \\
\hline \multirow[t]{5}{*}{ Mandipropamid } & 18 & 0.05 & - & $\mathrm{X}$ & - & - & - \\
\hline & 37 & 0.11 & - & $\mathrm{X}$ & - & - & - \\
\hline & 73 & 0.21 & - & $\mathrm{X}$ & - & - & - \\
\hline & 146 & 0.42 & $\mathrm{X}$ & $\mathrm{X}$ & 17 & $\mathrm{X}$ & $\mathrm{X}$ \\
\hline & 292 & 0.84 & - & - & 34 & $\mathrm{X}$ & - \\
\hline \multirow[t]{4}{*}{ Oxathiapiprolin } & 18 & 0.05 & - & $\mathrm{X}$ & - & - & - \\
\hline & 35 & 0.10 & - & $\mathrm{X}$ & - & - & - \\
\hline & 70 & 0.20 & $\mathrm{X}$ & $\mathrm{X}$ & 8 & $\mathrm{X}$ & $\mathrm{X}$ \\
\hline & 140 & 0.41 & $\mathrm{X}$ & $\mathrm{X}$ & 16 & $\mathrm{X}$ & - \\
\hline Potassium phosphite & - & - & - & - & $201^{x}$ & $\mathrm{X}$ & $\mathrm{X}$ \\
\hline Ethaboxam + fluopicolide & $351+210$ & $1.01+0.61$ & $\mathrm{X}$ & - & - & - & - \\
\hline Fluopicolide + mefenoxam & $210+1,122$ & $0.61+3.24$ & $\mathrm{X}^{\mathrm{y}}$ & - & - & - & \\
\hline Mefenoxam + oxathiapiprolin & $1,122+70$ & $3.24+0.20$ & $X^{z}$ & - & - & - & - \\
\hline Mefenoxam + oxathiapiprolin & $1,122+140$ & $3.24+0.41$ & $\mathrm{X}^{\mathrm{y}}$ & - & - & - & - \\
\hline
\end{tabular}

u Field rates per tree were calculated based on 346 trees/ha, greenhouse rates were calculated from field rates based on the soil area per tree:soil area per pot $=25: 1$. $\mathrm{v}-=$ Fungicide at the selected rate was not evaluated in the study, $\mathrm{X}=$ Fungicide at the selected rate was evaluated in the study.

${ }^{\mathrm{w}}$ Mefenoxam was used at $246 \mathrm{~g} / \mathrm{ha}$ in the first application, at $561 \mathrm{~g} / \mathrm{ha}$ in the second and third applications, and at $2,245 \mathrm{~g} / \mathrm{ha}$ in the last application.

${ }^{x}$ Recommended label rate for citrus seedlings was used $(31.3 \mathrm{ml}$ potassium phosphite/liter soil).

y Mefenoxam was applied at $246 \mathrm{~g} / \mathrm{ha}$ in the first three applications.

z Mefenoxam was applied at $123 \mathrm{~g} / \mathrm{ha}$ in the first three applications. 
Table 3. Univariate repeated-measures analysis of variance (ANOVA) ${ }^{\mathrm{w}}$ of Phytophthora root rot incidence, Phytophthora propagules per gram soil, and tree trunk diameter of navel orange infected by Phytophthora nicotianae in field studies

\begin{tabular}{|c|c|c|c|c|c|c|c|}
\hline Parameter & Source of variation & df & Type III sum of squares & F value & $P$ value & $\begin{array}{l}\text { Mauchly's test of } \\
\text { sphericity } P \text { value }\end{array}$ & $\begin{array}{l}\text { Adjusted } P \text { value } \\
\text { by } G^{-} G^{x}\end{array}$ \\
\hline \multirow[t]{10}{*}{ Root rot incidence ${ }^{y}$} & Block & 6 & 57.5 & 0.6333 & 0.7031 & & \\
\hline & Error (block) & 66 & 998.9 & & & & \\
\hline & Treatment & 11 & 4391.5 & 26.3774 & $<0.0001$ & & \\
\hline & Error (treatment) & 66 & 998.9 & & & & \\
\hline & Time & 2 & 376.8 & 8.4366 & 0.0004 & 0.0003 & 0.0009 \\
\hline & Error (time) & 132 & 2948.1 & & & & \\
\hline & Block $\times$ time & 12 & 201.2 & 0.7506 & 0.6996 & 0.0003 & 0.6735 \\
\hline & Error (block $\times$ time) & 132 & 2948.1 & & & & \\
\hline & Treatment $\times$ time & 22 & 1402.7 & 2.8548 & 0.0001 & 0.0003 & 0.0004 \\
\hline & Error (treatment $\times$ time) & 132 & 2948.1 & & & & \\
\hline \multirow[t]{10}{*}{ CFU per gram soill ${ }^{\mathrm{y}, \mathrm{z}}$} & Block & 6 & 11691 & 0.7639 & 0.6009 & & \\
\hline & Error (block) & 66 & 168340 & & & & \\
\hline & Treatment & 11 & 563615 & 20.0885 & $<0.0001$ & & \\
\hline & Error (treatment) & 66 & 168340 & & & & \\
\hline & Time & 2 & 24906 & 7.2457 & 0.0010 & 0.0144 & 0.0017 \\
\hline & Error (time) & 132 & 226861 & & & & \\
\hline & Block $\times$ time & 12 & 15415 & 0.7475 & 0.7028 & 0.0144 & 0.6873 \\
\hline & Error (block $\times$ time) & 132 & 226861 & & & & \\
\hline & Treatment $\times$ time & 22 & 103441 & 2.7358 & 0.0002 & 0.0144 & 0.0004 \\
\hline & Error (treatment $\times$ time) & 132 & 226861 & & & & \\
\hline \multirow[t]{10}{*}{ Tree trunk diameter ${ }^{y}$} & Block & 6 & 4637 & 11.4623 & $<0.0001$ & & \\
\hline & Error (block) & 318 & 21439 & & & & \\
\hline & Treatment & 11 & 2553 & 3.4424 & 0.0002 & & \\
\hline & Error (treatment) & 318 & 21439 & & & & \\
\hline & Time & 2 & 31654 & 1675.1265 & $<0.0001$ & $<0.0001$ & $<0.0001$ \\
\hline & Error (time) & 636 & 6009 & & & & \\
\hline & Block $\times$ time & 12 & 881 & 7.7738 & $<0.0001$ & $<0.0001$ & $<0.0001$ \\
\hline & Error (block $\times$ time) & 636 & 6009 & & & & \\
\hline & Treatment $\times$ time & 22 & 692 & 3.3289 & $<0.0001$ & $<0.0001$ & $<0.0001$ \\
\hline & Error (treatment $\times$ time) & 636 & 6009 & & & & \\
\hline \multirow[t]{10}{*}{ Tree canopy ${ }^{y}$} & Block & 6 & 5.96 & 6.6357 & $<0.0001$ & & \\
\hline & Error (block) & 66 & 9.87 & & & & \\
\hline & Treatment & 11 & 4.19 & 2.5445 & 0.0010 & & \\
\hline & Error (treatment) & 66 & 9.87 & & & & \\
\hline & Time & 1 & 122.45 & 1276.2644 & $<0.0001$ & & \\
\hline & Error (time) & 66 & 6.33 & & & & \\
\hline & Block $\times$ time & 6 & 1.72 & 2.9921 & 0.0120 & & \\
\hline & Error (block $\times$ time) & 66 & 6.33 & & & & \\
\hline & Treatment $\times$ time & 11 & 1.25 & 1.1816 & 0.3169 & & \\
\hline & Error (treatment $\times$ time $)$ & 66 & 6.33 & & & & \\
\hline \multirow{10}{*}{ Fruit number per tree } & Block & 4 & 20262 & 4.3327 & 0.0049 & & \\
\hline & Error (block) & 44 & 51443 & & & & \\
\hline & Treatment & 11 & 63765 & 4.9581 & $<0.0001$ & & \\
\hline & Error (treatment) & 44 & 51443 & & & & \\
\hline & Time & 1 & 514568 & 376.2906 & $<0.0001$ & & \\
\hline & Error (time) & 44 & 60169 & & & & \\
\hline & Block $\times$ time & 4 & 4933 & 0.9018 & 0.4712 & & \\
\hline & Error (block $\times$ time) & 44 & 60169 & & & & \\
\hline & Treatment $\times$ time & 11 & 33472 & 2.2252 & 0.0301 & & \\
\hline & Error (treatment $\times$ time) & 44 & 60169 & & & & \\
\hline \multirow[t]{10}{*}{ Fruit weight per tree ${ }^{y}$} & Block & 4 & 1448 & 2.3448 & 0.0693 & & \\
\hline & Error (block) & 44 & 6795 & & & & \\
\hline & Treatment & 11 & 8250 & 4.8567 & $<0.0001$ & & \\
\hline & Error (treatment) & 44 & 6795 & & & & \\
\hline & Time & 1 & 6706 & 922.4177 & $<0.0001$ & & \\
\hline & Error (time) & 44 & 6692 & & & & \\
\hline & Block $\times$ time & 4 & 718 & 1.1800 & 0.3328 & & \\
\hline & Error (block $\times$ time) & 44 & 6692 & & & & \\
\hline & Treatment $\times$ time & 11 & 5928 & 3.5432 & 0.0013 & & \\
\hline & Error (treatment $\times$ time) & 44 & 6692 & & & & \\
\hline
\end{tabular}

${ }^{\mathrm{w}}$ Univariate repeated-measures ANOVA was performed in R (3.1.3).

${ }^{x} P$ value was adjusted using Greenhouse-Geisser correction.

${ }^{y}$ For parameters that were measured three times during the trial period, Mauchly's test was performed for sphericity. When sphericity was violated $(P<0.05)$, adjusted $P$ values were used to determine the significance of variance. For tree canopy, fruit number, and fruit weight, only two repeated measures were done.

$\mathrm{z}$ Colony forming units (CFU) were determined by soil plating. 
rinsed with water. Soil and feeder roots were plated on duplicate plates of PARHFB-V8C medium as described above for field studies to assess root rot incidence and $P$. nicotianae propagule soil populations. This experiment was done twice.

In another experiment, 10- to 12-month-old plants were inoculated with $P$. citrophthora (isolate 2440, Table 1) that was grown on longgrain white rice (Holmes and Benson 1994) for 4 weeks. For inoculation, two colonized rice grains were buried $3 \mathrm{~cm}$ deep at each of four locations around each plant (8 grains/pot). Fungicides (Table 2) were applied as described above after 1 week. A randomized complete block design with four single-pot replications was used for each treatment. Plants treated with water were used as controls. After 4-5 months, the efficacy of fungicides was evaluated as described above. This experiment was repeated.

Statistical analysis. For field trials, data for Phytophthora root rot incidence and Phytophthora propagule populations in soil, tree trunk diameters, tree canopy sizes, and fruit production at different evaluation times were subjected to a repeated measures univariate analysis of variance (ANOVA) to determine the effect of fungicide treatments over the trial periods. Mauchly's test for sphericity was performed to test the equality of variance of the differences between all combinations of factors at each measurement time when more than two repeated measurements were conducted. When sphericity was violated $(P<0.05)$, valid $P$ values were obtained using the GreenhouseGeisser correction. Differences between means of treatments at each measurement time were analyzed using Fisher's least significant difference (LSD) test, and differences between the means of the control and fungicide treatments were analyzed using pairwise $t$ tests.

For repeated greenhouse experiments, the homogeneity of variances for Phytophthora root rot incidence and Phytophthora propagule populations in soil were tested using Bartlett's test of homogeneity. Homogeneous data were combined and analyzed using ANOVA, and the differences between means of treatments were compared using a pairwise $t$ test and Fisher's LSD test.

All statistical analyses were performed in R (version 3.1.3; R Core Team 2015) using the agricolae (De Mendiburu 2015) and car (Fox

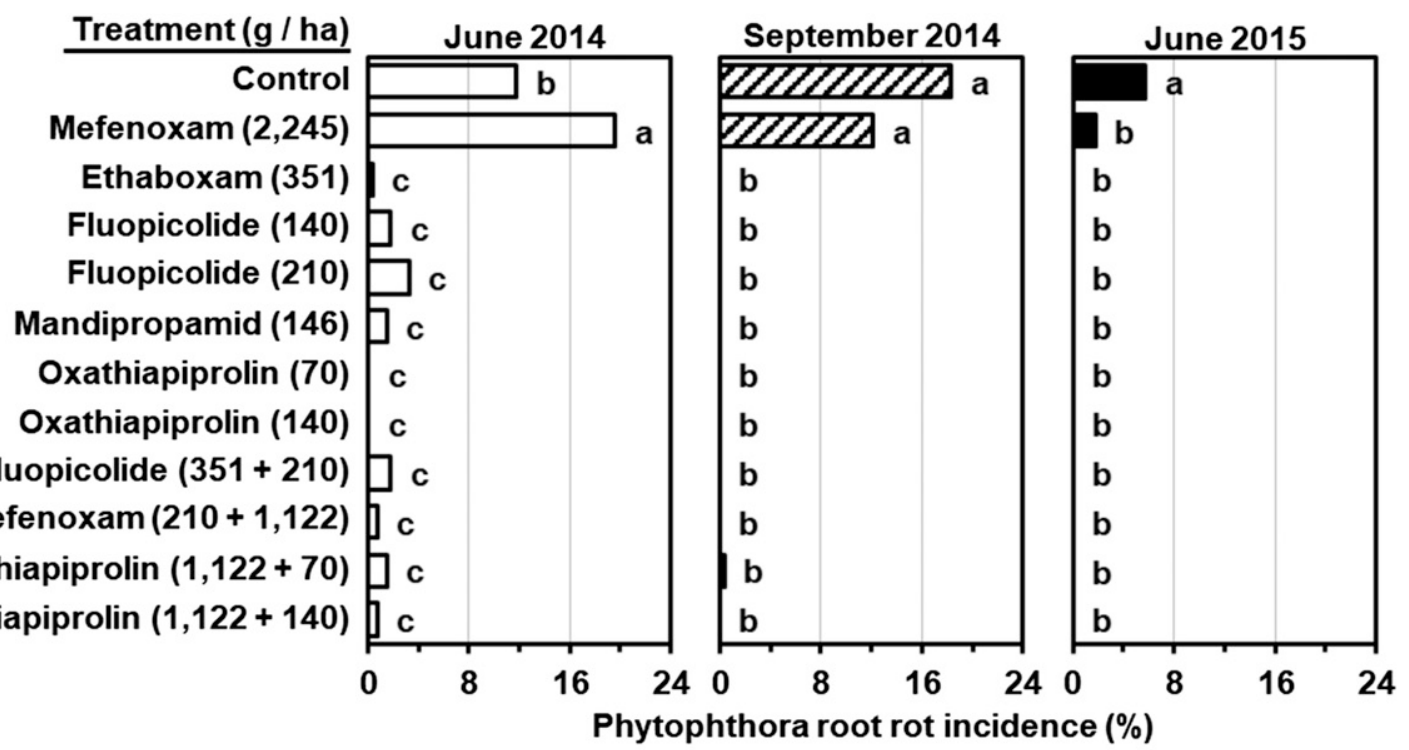

B

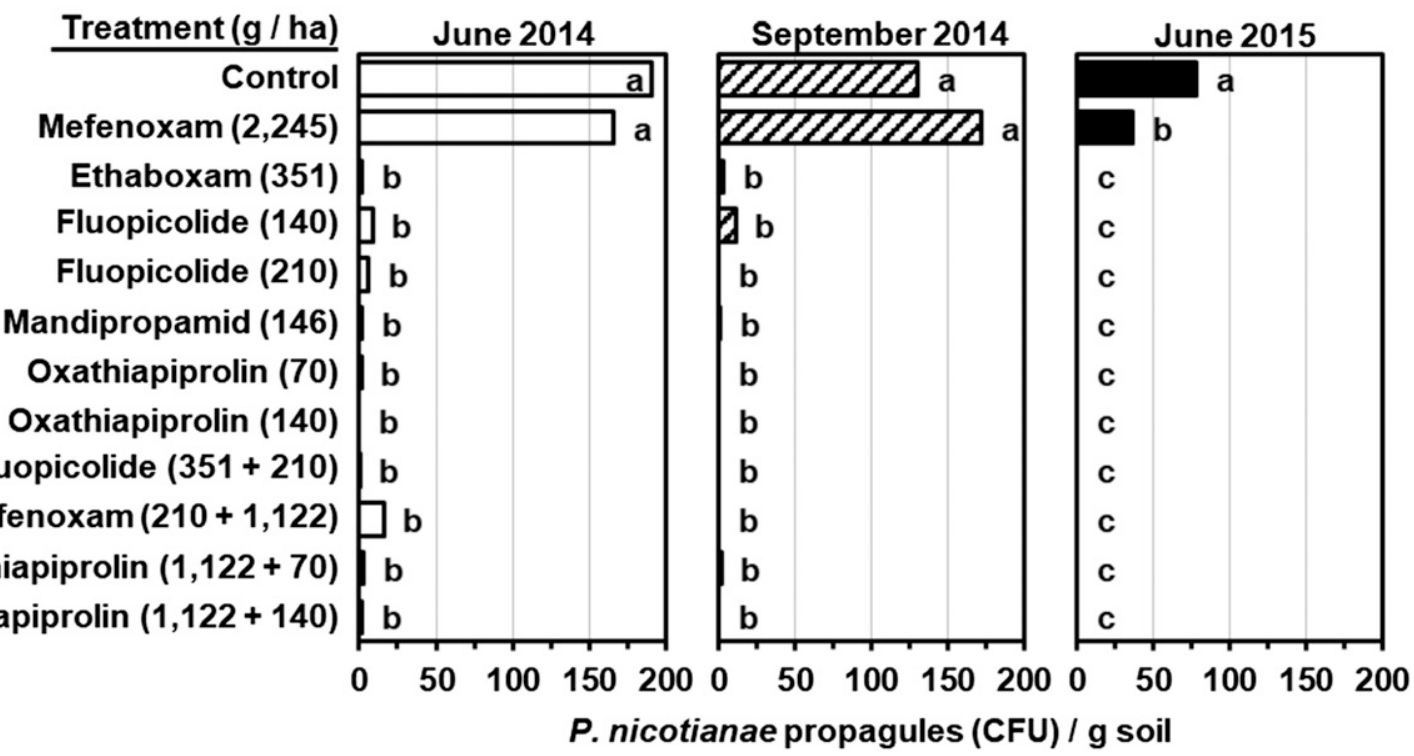

Fig. 1. Efficacy of fungicides in reducing A, incidence of Phytophthora root rot of navel orange on 'Carrizo citrange' rootstock caused by Phytophthora nicotianae and B, pathogen populations in the soil in a field trial initiated in September 2013. Fungicides were applied in October 2013, June and September 2014, and May 2015. Mefenoxam used by itself was applied at $246 \mathrm{~g} / \mathrm{ha}$ in the first application, at $561 \mathrm{~g} / \mathrm{ha}$ in the second and third applications, and at 2,245 g/ha in the fourth application. In the fluopicolide-mefenoxam and mefenoxam-oxathiapiprolin (140 g/ha) mixtures, mefenoxam was applied at $246 \mathrm{~g} / \mathrm{ha}$ in the first three applications, whereas in the mefenoxam-oxathiapiprolin $(70 \mathrm{~g} / \mathrm{ha})$ mixture, mefenoxam was applied at $123 \mathrm{~g} / \mathrm{ha}$ in the first three applications. Feeder roots and rhizosphere soil were sampled in June and September 2014 (before the second and third fungicide applications, respectively), and June 2015 (after the fourth application). Bars followed by the same letter do not differ significantly according to Fisher's least significance difference test at $P=0.05$. 
and Weisberg 2011) packages. Results were considered significant at $P \leq 0.05$.

\section{Results}

Efficacy of new fungicides against Phytophthora root rot of navel orange caused by $\boldsymbol{P}$. nicotianae in field studies. There were significant main effects of sampling time for Phytophthora root rot incidence $(P=0.0009)$ and $P$. nicotianae propagule soil populations $(P=0.0017)$ and a significant interaction between sampling time and fungicide treatment on the incidence of Phytophthora root $\operatorname{rot}(P=$ $0.0004)$ and $P$. nicotianae propagules in soil $(P=0.0004)$ (Table 3$)$. Seven months after the first fungicide application (June 2014), all fungicide treatments (including mixtures), except mefenoxam by itself, significantly $(P \leq 0.0002)$ reduced the incidence of Phytophthora root rot to low levels as compared with the control (Fig. 1A). Three months after the second application (September 2014), treatments with the new fungicides reduced the incidence to zero or near zero levels. Mefenoxam was only effective after the rate was increased to $2,245 \mathrm{~g} / \mathrm{ha}$ at the fourth application (June 2015). Fungicide effects on soil population sizes of $P$. nicotianae were very similar as for root rot incidence, and populations were dramatically decreased by treatments containing the new compounds starting after the first application (Fig. 1B).

For tree trunk diameters, a significant effect of measurement time $(P<0.0001)$ and a significant interaction between measurement time and treatment $(P<0.0001)$ were found (Table 3$)$. Differences in trunk diameters among treated and control trees were observed in July and December 2015 (Table 4) after the fourth fungicide application. In July, diameters were significantly larger $(P \leq 0.0424)$ after treatments containing fluopicolide or oxathiapiprolin, and in December, ethaboxam-treated trees also showed increased trunk diameters. In July and December evaluations, trunk diameters after mandipropamid or mefenoxam treatments by themselves, however, were similar $(P \geq 0.1496)$ to those of control trees.

Two-dimensional tree canopy sizes were significantly different among treatments $(P<0.0010)$ and between measurement times $(P<0.0001)$ (Table 3). In April 2015 and 2016, canopy sizes were significantly larger in comparison with control trees after treatment with the lower and higher rates of fluopicolide $(P=0.0024$ and $P=$ 0.0199 , or $P=0.0391$ and $P=0.0498$, for April 2015 and 2016, respectively), the lower and higher rates of oxathiapiprolin $(P=0.0427$ and $P=0.0426$, or $P=0.0334$ and $P=0.0428$, respectively), or the ethaboxam-fluopicolide mixture $(P=0.0242$ and $P=0.0020$, respectively) (Table 4). For other treatments, no differences in canopy size as compared with the control were found in both evaluations (ethaboxam: $P=0.2766$ and $P=0.0993$; mandipropamid: $P=$ 0.3113 and $P=0.2716$; mefenoxam: $P=0.9289$ and $P=0.6927$; mefenoxam mixed with a low rate of oxathiapiprolin: $P=0.1071$

Table 5. Univariate repeated-measures analysis of variance (ANOVA) ${ }^{\mathrm{x}}$ for Phytophthora root rot incidence and Phytophthora propagules per gram of soi in a field study with Phytophthora citrophthora-infected navel orange trees

\begin{tabular}{llrrrr}
\hline Parameter & Source of variation & df & $\begin{array}{c}\text { Type III sum } \\
\text { of squares }\end{array}$ & F value & $\boldsymbol{P}$ value \\
\hline $\begin{array}{l}\text { Root rot } \\
\text { incidencey }\end{array}$ & Block & 5 & 394.6 & 2.6211 & 0.0302 \\
& Error (block) & 80 & 2409.0 & & \\
& Treatment & 16 & 2000.9 & 4.1530 & $<0.0001$ \\
& Error (treatment) & 80 & 2409.0 & & \\
& Time & 1 & 717.2 & 26.2220 & $<0.0001$ \\
& Error (time) & 80 & 2188.1 & & \\
& Block $\times$ time & 5 & 326.0 & 2.3839 & 0.0455 \\
& Error (block $\times$ time) & 80 & 2188.1 & & \\
& Treatment $\times$ time & 16 & 834.4 & 1.9067 & 0.0316 \\
& Error (treatment $\times$ & 80 & 2188.1 & & \\
time) & & & & \\
CFU per & Block & 5 & 291331 & 1.0837 & 0.3758 \\
gram soil (1,z & Error (block) & 80 & 4301141 & & \\
& Treatment & 16 & 4410695 & 5.1274 & $<0.0001$ \\
& Error (treatment) & 80 & 4301141 & & \\
& Time & 1 & 3047815 & 56.9863 & $<0.0001$ \\
& Error (time) & 80 & 4278662 & & \\
Block $\times$ time & 5 & 292411 & 1.0935 & 0.3706 \\
& Error (block $\times$ time) & 80 & 4278662 & & \\
Treatment $\times$ time & 16 & 3463375 & 4.0473 & $<0.0001$ \\
& Error (treatment $\times$ & 80 & 4278662 & & \\
time) & & & & \\
\hline
\end{tabular}

${ }^{\mathrm{x}}$ Univariate repeated-measures ANOVA was performed in $\mathrm{R}$ (3.1.3).

${ }^{y}$ All parameters were measured twice during the field trial period.

${ }^{\mathrm{z}}$ Colony forming units (CFU) were determined by soil plating.

Table 4. Tree trunk diameter, tree canopy size, and fruit production of navel orange trees treated with fungicides to manage Phytophthora root rot caused by Phytophthora nicotianae

\begin{tabular}{|c|c|c|c|c|c|c|c|c|c|}
\hline \multirow[b]{3}{*}{ Treatment (g / ha) } & \multirow{2}{*}{\multicolumn{3}{|c|}{ Tree trunk diameter $(\mathbf{m m})^{\mathrm{u}}$}} & \multirow{2}{*}{\multicolumn{2}{|c|}{ Tree canopy $\left(\mathbf{m}^{2}\right)^{\mathbf{v}}$}} & \multicolumn{4}{|c|}{ Fruit production } \\
\hline & & & & & & \multicolumn{2}{|c|}{ Dec 2016} & \multicolumn{2}{|c|}{ Dec 2017} \\
\hline & $\begin{array}{l}\text { Feb } \\
2015\end{array}$ & $\begin{array}{c}\text { Jul } \\
2015\end{array}$ & $\begin{array}{l}\text { Dec } \\
2015\end{array}$ & $\begin{array}{l}\text { Apr } \\
2015\end{array}$ & $\begin{array}{l}\text { Apr } \\
2016\end{array}$ & Fruit no. / tree & $\begin{array}{l}\text { Fruit weight } \\
\text { (kg) / tree }\end{array}$ & Fruit no. / tree & $\begin{array}{c}\text { Fruit weight } \\
\text { (kg) / tree }\end{array}$ \\
\hline Control & $26.6 \mathrm{ab}^{\mathrm{w}}$ & $31.2 \mathrm{~cd}$ & $36.1 \mathrm{c}$ & $0.5 \mathrm{c}$ & $1.9 \mathrm{~d}$ & $56 \mathrm{~d}$ & $13.0 \mathrm{c}$ & $144 \mathrm{~cd}$ & $60.5 \mathrm{de}$ \\
\hline Mefenoxam $(2,245)^{\mathrm{x}}$ & $24.0 \mathrm{c}$ & $30.6 \mathrm{~d}$ & $35.8 \mathrm{c}$ & $0.5 \mathrm{c}$ & $2.0 \mathrm{~cd}$ & $60 \mathrm{~cd}$ & $13.1 \mathrm{c}$ & $122 \mathrm{~d}$ & $53.6 \mathrm{e}$ \\
\hline Ethaboxam (351) & $27.3 \mathrm{ab}$ & $33.5 \mathrm{bc}$ & $39.6 \mathrm{~b}$ & $0.6 \mathrm{bc}$ & $2.4 \mathrm{abcd}$ & $68 \mathrm{bcd}$ & $15.3 \mathrm{bc}$ & $219 a b$ & $89.2 \mathrm{abc}$ \\
\hline Fluopicolide (140) & $27.4 \mathrm{ab}$ & $35.5 \mathrm{ab}$ & $41.8 \mathrm{ab}$ & $0.7 \mathrm{ab}$ & $2.5 \mathrm{abc}$ & $81 \mathrm{abc}$ & $16.8 \mathrm{abc}$ & $242 a b$ & $100.4 \mathrm{ab}$ \\
\hline Fluopicolide (210) & $26.7 \mathrm{ab}$ & $35.1 \mathrm{ab}$ & $41.8 \mathrm{ab}$ & $0.8 \mathrm{a}$ & $2.6 \mathrm{ab}$ & $92 \mathrm{a}$ & $19.9 \mathrm{a}$ & $217 \mathrm{ab}$ & $88.1 \mathrm{abc}$ \\
\hline Mandipropamid (146) & $25.2 \mathrm{bc}$ & $33.0 \mathrm{bcd}$ & $38.7 \mathrm{bc}$ & $0.6 \mathrm{bc}$ & $2.2 \mathrm{bcd}$ & $72 \mathrm{abcd}$ & $16.6 \mathrm{abc}$ & $239 \mathrm{ab}$ & $103.2 \mathrm{a}$ \\
\hline Oxathiapiprolin (70) & $25.5 \mathrm{abc}$ & $35.4 \mathrm{ab}$ & $41.6 \mathrm{ab}$ & $0.7 \mathrm{ab}$ & $2.5 \mathrm{abc}$ & $88 \mathrm{ab}$ & $18.8 \mathrm{ab}$ & $259 \mathrm{a}$ & $99.8 \mathrm{ab}$ \\
\hline Oxathiapiprolin (140) & $27.0 \mathrm{ab}$ & $35.2 \mathrm{ab}$ & $40.9 \mathrm{~b}$ & $0.7 \mathrm{ab}$ & $2.4 \mathrm{abc}$ & $72 \mathrm{abcd}$ & $15.7 \mathrm{bc}$ & $242 a b$ & $100.8 \mathrm{ab}$ \\
\hline $\begin{array}{l}\text { Ethaboxam + fluopicolide } \\
(351+210)\end{array}$ & $27.3 \mathrm{ab}$ & $36.7 \mathrm{a}$ & $44.3 \mathrm{a}$ & $0.7 \mathrm{ab}$ & $2.8 \mathrm{a}$ & $90 \mathrm{a}$ & $18.9 \mathrm{ab}$ & $196 \mathrm{bc}$ & $85.8 \mathrm{abc}$ \\
\hline $\begin{array}{l}\text { Fluopicolide + mefenoxam } \\
(210+1,122)^{\mathrm{y}}\end{array}$ & $26.9 \mathrm{ab}$ & $35.3 \mathrm{ab}$ & $40.8 \mathrm{~b}$ & $0.7 \mathrm{ab}$ & $2.4 \mathrm{abcd}$ & $80 \mathrm{abc}$ & $17.6 \mathrm{ab}$ & $196 \mathrm{bc}$ & $79.8 \mathrm{bcd}$ \\
\hline $\begin{array}{l}\text { Mefenoxam + oxathiapiprolin } \\
(1,122+70)^{\mathrm{z}}\end{array}$ & $27.7 \mathrm{a}$ & $34.1 \mathrm{ab}$ & $40.4 \mathrm{~b}$ & $0.6 \mathrm{~b}$ & $2.3 \mathrm{bcd}$ & $73 \mathrm{abcd}$ & $15.5 \mathrm{bc}$ & $196 \mathrm{bc}$ & $75.1 \mathrm{cde}$ \\
\hline $\begin{array}{l}\text { Mefenoxam + oxathiapiprolin } \\
(1,122+140)^{\mathrm{y}}\end{array}$ & $27.3 \mathrm{ab}$ & $34.5 \mathrm{ab}$ & $41.4 \mathrm{ab}$ & $0.7 \mathrm{ab}$ & $2.4 \mathrm{abcd}$ & 76 abcd & $15.9 \mathrm{abc}$ & $208 \mathrm{ab}$ & $81.3 \mathrm{abcd}$ \\
\hline
\end{tabular}

u Tree trunk diameter was measured $10 \mathrm{~cm}$ above the graft union.

$\checkmark$ The two-dimensional tree canopy area was calculated as percent area covered by the tree canopy of a blue standard background using Assess 1.0 .

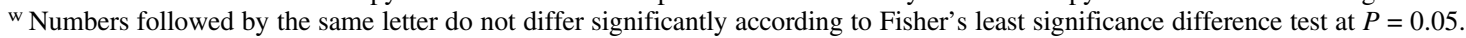

${ }^{\mathrm{x}}$ Mefenoxam was used at $246 \mathrm{~g} / \mathrm{ha}$ in the first application, at $561 \mathrm{~g} / \mathrm{ha}$ in the second and third applications, and at 2,245 g/ha in the last application.

${ }^{y}$ Mefenoxam was applied at $246 \mathrm{~g} / \mathrm{h}$ a in the first three applications.

${ }^{\mathrm{z}}$ Mefenoxam was applied at $123 \mathrm{~g} / \mathrm{ha}$ in the first three applications. 
and $P=0.2007$, respectively). A significant increase in canopy size was only observed in April 2015 for fluopicolide mixed with mefenoxam $(P=0.0172$ and $P=0.0770$, for 2015 and 2016, respectively); and for mefenoxam mixed with a higher rate of oxathiapiprolin $(P=$ 0.0332 and $P=0.0944$, respectively). No phytotoxic effects to trees such as leaf burn were observed for any of the treatments.

Fruit production was assessed in December 2016 and 2017. A significant effect of evaluation time $(P<0.0001$ for fruit number per tree and $P<0.0001$ for fruit weight per tree) and a significant interaction between evaluation time and treatment $(P=0.0301$ for fruit number and $P=0.0013$ for fruit weight) were observed (Table 3 ). In both years, significant increases in fruit number and weight as compared with control trees were observed after treatment with the $210-\mathrm{g} / \mathrm{ha}$ rate of fluopicolide $(P=0.0058 / 0.0047$ and $P=0.0239 / 0.0173$ for fruit number/fruit weight in December 2016 and 2017 harvests, respectively), the $70-\mathrm{g} /$ ha rate of oxathiapiprolin $(P=0.0120 / 0.0164$ and $P=0.0006 / 0.0010$, respectively), and the ethaboxamfluopicolide mixture $(P=0.0082 / 0.0140$ and $P=0.0222 / 0.0274$, respectively) (Table 4). In the 2017 evaluation, 4 years after orchard establishment, the number of fruit per tree was significantly higher $(P \leq 0.0239)$ for all single-active-ingredient treatments except for mefenoxam used by itself $(P=0.4876)$. At this time, fruit weight per tree was significantly $(P \leq 0.0173)$ increased by all singleactive-ingredient treatments except for mefenoxam $(P=0.5412)$, the fluopicolide-mefenoxam mixture $(P=0.0904)$, and the mefenoxam $(1,122 \mathrm{~g} / \mathrm{ha})$-oxathiapiprolin $(140 \mathrm{~g} / \mathrm{ha})$ mixture $(P=$ $0.0689)$. The highest yields were obtained after treatment with mandipropamid (103.2 kg/tree; as compared with $60.5 \mathrm{~kg}$ for control trees), the $140-\mathrm{g} / \mathrm{ha}$ rate of fluopicolide $(100.4 \mathrm{~kg} / \mathrm{tree})$, and oxathiapiprolin $(99.8$ and $100.8 \mathrm{~kg} /$ tree for the $70-\mathrm{g}$ and $140 \mathrm{-g} / \mathrm{ha}$ rates, respectively).

Evaluation of fungicide application rates to manage Phytophthora root rot of navel orange caused by $P$. citrophthora in field studies. There were significant main effects of sampling time for root rot incidence $(P<0.0001)$ and $P$. citrophthora propagule soil populations $(P<0.0001)$ and a significant interaction between sampling time and fungicide treatment on the incidence of root rot $(P=0.0316)$ and $P$. citrophthora propagules in soil $(P<0.0001)$ (Table 5). In an evaluation of root rot incidence after the first treatment (December 2016), applications with ethaboxam and mandipropamid resulted in rate-dependent differences in efficacy, and higher rates were generally more effective (Fig. 2). For ethaboxam, only the highest rate ( $140 \mathrm{~g} / \mathrm{ha}, P=0.0299)$, and for mandipropamid, the two highest rates $(73 \mathrm{~g} / \mathrm{ha}$ and $146 \mathrm{~g} / \mathrm{ha}, P=0.0112$ and $P=0.0086$, respectively) evaluated resulted in a significant difference in root rot incidence from the control. For fluopicolide and oxathiapiprolin, there was no significant difference among rates $(P \geq 0.7019$ for $35 \mathrm{~g}$ to $281 \mathrm{~g}$ fluopicolide/ha; and $P \geq 0.2939$ for $18 \mathrm{~g}$ to $140 \mathrm{~g}$ oxathiapiprolin/ha), and all four rates evaluated were highly effective ( $P \leq 0.0186$ for fluopicolide, $P \leq 0.0086$ for oxathiapiprolin). In the second evaluation in July 2017, all treatments, except an intermediate rate of ethaboxam were statistically similarly effective in reducing the incidence of root rot (Fig. 2). Results for P. citrophthora soil populations mostly reflected those for root rot incidence. However, fluopicolide also showed rate-dependent differences, with the highest rate of $281 \mathrm{~g} /$ ha being the most effective $(P=0.0145)$ in the first evaluation in December 2016 (Fig. 2).

Evaluation of new fungicides against Phytophthora root rot of orange in greenhouse studies. Variances of data from repeated experiments were homogeneous and therefore, results presented are the mean of two experiments. Similar to the field studies, ethaboxam, fluopicolide, mandipropamid, and oxathiapiprolin effectively reduced the incidence of root $\operatorname{rot}(P<0.0001)$ and soil population sizes of $P$. nicotianae $(P<0.0001)$ to zero or near zero levels (Fig. 3$)$. There was no significant difference in efficacy between the two rates of each fungicide evaluated ( $P \geq 0.79$ for root rot incidence, and $P \geq$ 0.8805 for $P$. nicotianae soil populations, respectively). Mefenoxam was significantly less effective in reducing soil populations than the

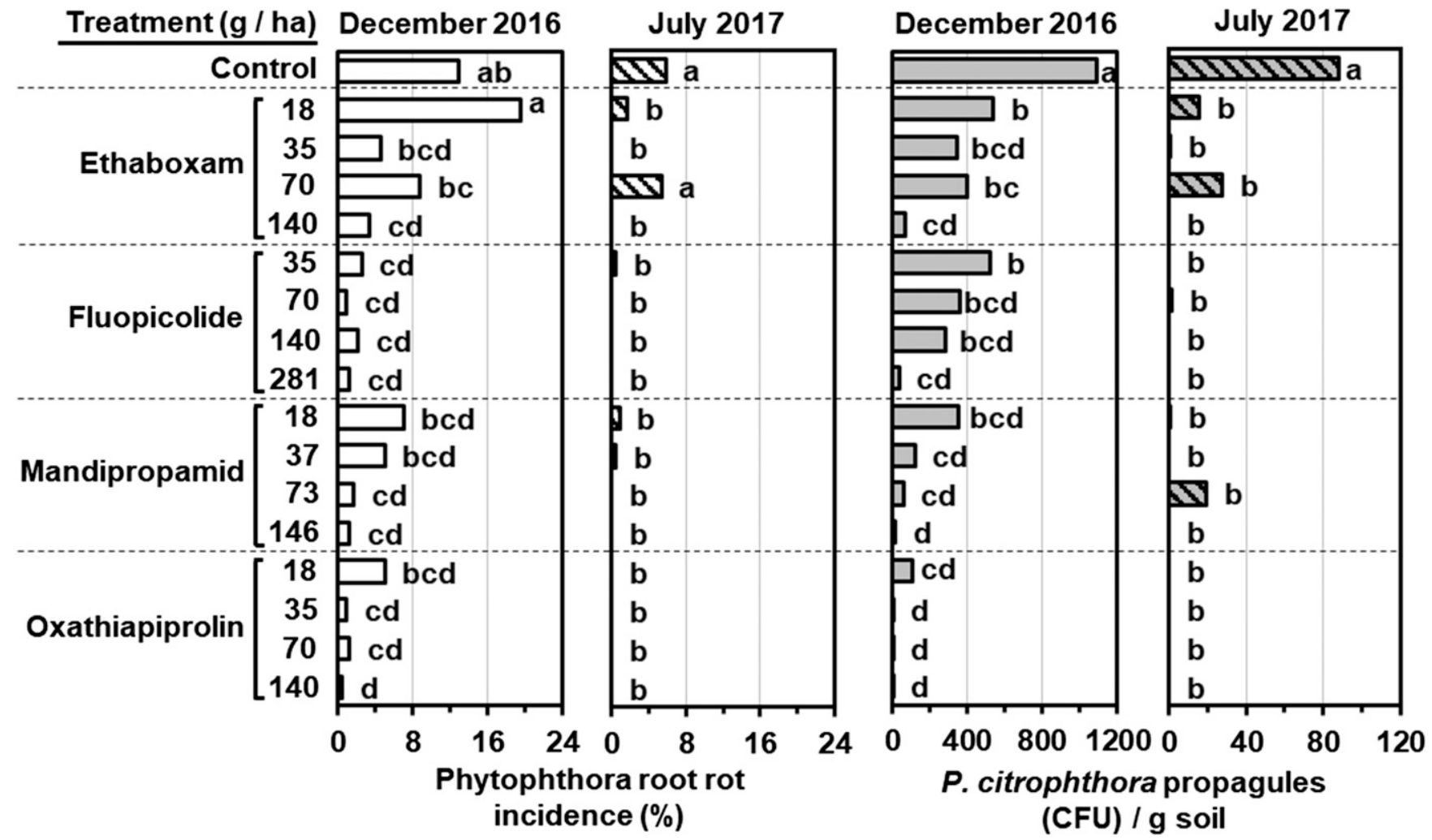

Fig. 2. Efficacy of selected rates of new Oomycota fungicides in reducing the incidence of Phytophthora root rot of navel orange on 'Carrizo citrange' rootstock caused by Phytophthora citrophthora and pathogen populations in the soil in a field trial initiated in June 2016. Fungicides were applied in July 2016 and May 2017. Feeder roots and rhizosphere soil were sampled in December 2016 and July 2017. Bars followed by the same letter do not differ significantly according to Fisher's least significance difference test at $P=0.05$. 
other fungicides, but populations were still significantly $(P<0.0001)$ lower as compared with the control. Potassium phosphite was also highly effective using the label rate for nursery use and significantly $(P<0.0001)$ reduced root rot incidence and $P$. nicotianae propagules in the soil. No phytotoxicity was observed on plants with any of the treatments at the rates used, but higher rates of mefenoxam and potassium phosphite used in other studies caused stunting and dieback (data not presented).

In another greenhouse study, orange plants were inoculated with $P$. citrophthora after soil treatment. Applications with fungicides were done at the lower of the two rates used in the greenhouse study above with $P$. nicotianae. Although disease incidence in the untreated control was low, significant reductions $(P<0.0001$ for root rot incidence and $P$. citrophthora populations) were obtained using ethaboxam, fluopicolide, mandipropamid, or oxathiapiprolin, and root rot incidence and soil populations were reduced to zero or very low levels (Fig. 4). Mefenoxam and potassium phosphite were effective against root rot and showed moderate activity in reducing pathogen soil populations.

\section{Discussion}

This is the first study evaluating the new Oomycota fungicides ethaboxam, fluopicolide, mandipropamid, and oxathiapiprolin for managing Phytophthora root rot of citrus. Among soil-borne diseases of citrus, Phytophthora root rot is the most serious, occurring in most growing regions worldwide, whereas others including Armillaria root rot (caused by Armillaria spp.), dry root rot (caused by Fusarium solani), and Rosellinia root rot (caused by Rosellinia necatrix) are of only localized importance (Adaskaveg et al. 2014). Therefore, effective management strategies for Phytophthora root rot need to be available, also in light of increasing restrictions on the use of soil fumigants for preparation of new planting sites. Moreover, there is some evidence for a positive interaction between infection levels by huanglongbing (HLB) and Phytophthora root rot and for an enhancement of HLB-induced symptoms in P. nicotianae-infected citrus plants (Graham et al. 2011, 2013). This further stresses the significance of our study.

In comparative studies with the current commercial standards, mefenoxam and potassium phosphite, we demonstrated the superior effectiveness of ethaboxam, fluopicolide, mandipropamid, and

\section{Treatment (mg / pot)}

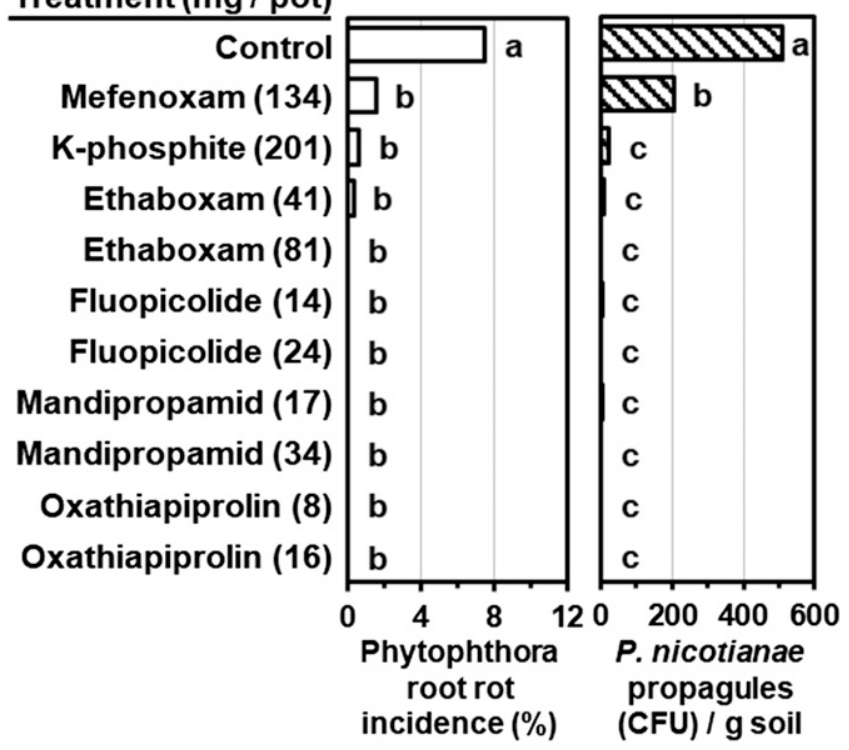

Fig. 3. Efficacy of new Oomycota fungicides against Phytophthora root rot caused by Phytophthora nicotianae in greenhouse studies with 'Madam Vinous' sweet orange seedlings. Fungicides were applied 1 week after soil inoculation. The incidence of Phytophthora root rot and pathogen soil populations were evaluated after 7 months. Data are the averages of two experiments. Bars followed by the same letter do not differ significantly according to Fisher's least significance difference test at $P=0.05$. oxathiapiprolin in reducing Phytophthora spp. soil populations and root rot in field and greenhouse studies as well as increasing crop yield. Our field studies established fungicide effectiveness under California orchard conditions using a common commercial irrigation system that exposes the tree rhizosphere to regular wetness conditions and potential infection periods for the root rot pathogens. In the field study with $P$. citrophthora, we identified lower highly effective rates for mandipropamid ( $73 \mathrm{~g}$ versus $146 \mathrm{~g} / \mathrm{ha}$ ) and oxathiapiprolin ( $35 \mathrm{~g}$ versus $70 \mathrm{~g} / \mathrm{ha}$ ) when results were compared with the first field study on root rot caused by $P$. nicotianae that used rates originally recommended by the respective registrants. Fungicide rate calculations for plants in the greenhouse were based on pot surface area in comparison with tree trunk basin area in the field. Although the greenhouse-applied rates may still not be equivalent to labeled field rates, these studies demonstrated postinfection activity of the fungicides. This is important because the disease in a newly planted field may be initiated from infected nursery stock.

The high efficacy of ethaboxam, fluopicolide, mandipropamid, and oxathiapiprolin in reducing disease and Phytophthora soil populations correlated with their low in vitro effective concentration (EC) values against mycelial growth of several Phytophthora species from citrus that we determined previously (Gray et al. 2018). The isolates of $P$. nicotianae and $P$. citrophthora in the current study were used as representatives of each species with $\mathrm{EC}_{50}$ values for each fungicide within the baseline range of sensitivity. In the Gray et al. (2018) study, values for oxathiapiprolin were the lowest among the four compounds for inhibition of five Phytophthora life stages including mycelial growth, sporangium formation, zoospore cyst germination, and chlamydospore and oospore formation. This high toxicity was reflected by low effective field rates (i.e., $35 \mathrm{~g} / \mathrm{ha}$ ) that we identified in the field study with $P$. citrophthora.

Ethaboxam (Cortright et al. 2016; Kim et al. 2004), fluopicolide and mandipropamid (Cerkauskas et al. 2015; Foster and Hausbeck 2010; Jackson et al. 2010; Jiang et al. 2015; Meyer and Hausbeck 2013; Shin et al. 2010), and oxathiapiprolin (Bittner and Mila 2016; Ji and Csinos 2015; Ji et al. 2014; Miao et al. 2016) were previously shown to provide a high level of control for a range of foliar and root diseases of field and vegetable crops caused by species of Phytophthora. However, our study is the first validation of the effective use of the new compounds on a perennial tree crop, and the results presented are facilitating their registration on citrus. We conducted our studies using orange trees inoculated with $P$. nicotianae or P. citrophthora, the main Phytophthora root rot pathogens

Treatment (mg/ pot)

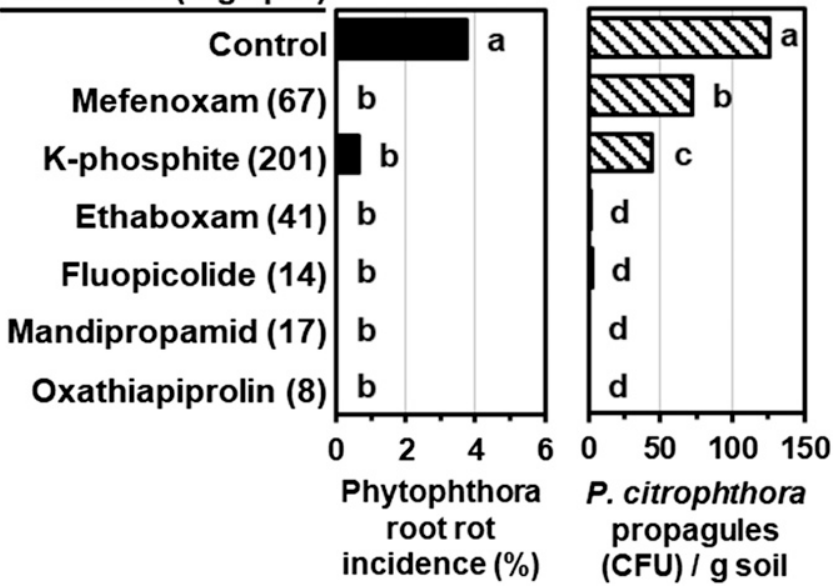

Fig. 4. Efficacy of new Oomycota fungicides against Phytophthora root rot caused by Phytophthora citrophthora in greenhouse studies with 'Madam Vinous' sweet orange seedlings. Fungicides were applied 1 week after soil inoculation. The incidence of Phytophthora root rot and pathogen soil populations were evaluated after 5 months. Data are the averages of two repeated experiments. Bars followed by the same letter do not differ significantly according to Fisher's least significance difference test at $P=0.05$. 
in California (Hao et al. 2016). Additional species are major causal agents in other citrus growing areas, for example $P$. palmivora in Florida (Graham and Menge 1999), and further studies using these species may be warranted.

In comparison with the four new fungicides, effectiveness of potassium phosphite in greenhouse studies was high to moderate and was moderate for mefenoxam. In the field study, a significant reduction in disease and soil populations by mefenoxam was only observed after increasing applications to high label rates. Lower rates were initially used because this fungicide is known to cause phytotoxic effects to young citrus trees as was also observed in preliminary greenhouse studies (data not presented here) where a range of rates was evaluated. Thus, the reduced effectiveness of mefenoxam in our study, a treatment that has been used successfully in commercial applications for managing Phytophthora root rot of various tree crops for many years, may have been due to using inadequate rates. Furthermore, trees were inoculated with an isolate of $P$. nicotianae with an $\mathrm{EC}_{50}$ value for mycelial growth of $0.24 \mathrm{mg} / \mathrm{liter}$ that was in the midrange among 31 isolates from California evaluated previously (Gray et al. 2018). Because baseline sensitivities before commercial use of mefenoxam were never established for $P$. nicotianae from citrus, and the phenylamide class of fungicides has been used since the 1980s in California citriculture, this isolate may be part of a lesssensitive subpopulation of the species that cannot be easily managed with mefenoxam applications.

Soil populations of untreated control trees in our field and greenhouse studies were often very high considering that $>15$ propagules $/ g$ of soil is considered a threshold level where management is recommended (Adaskaveg et al. 2014; Lutz and Menge 1986). Still, disease incidence of feeder roots was mostly low, especially during summer samplings in the field. We chose Carrizo citrange in the field studies because it is commonly used commercially as a rootstock. It is considered of intermediate susceptibility (Ferguson et al. 1990) or tolerant (Graham and Menge 1999) to Phytophthora root rot, and this could have accounted for the low disease incidence. In the greenhouse studies, disease incidence may have been increased by pruning feeder roots of seedlings as it was done in studies by others (Graham 1995). Root injuries may occur naturally in the field by nematode or root weevil (Diaprepes spp.) infestations in the soil, and these pests are known to increase the incidence of Phytophthora root rot (Graham and Menge 1999; Graham et al. 2003). Still, although disease incidence was overall low in our studies, fungicide efficacy could be compared and significant differences were observed.

The four new Oomycota fungicides are single-site mode of action inhibitors (Blum et al. 2010; Pasteris et al. 2016; Toquin et al. 2006; Uchida et al. 2005). Their resistance risk currently has not been completely characterized (FRAC 2018), and resistant field isolates have not yet been detected in Phytophthora species (Gisi and Sierotzki 2015; Lu et al. 2011; Saville et al. 2015). Resistance, however, has been described for Plasmopara viticola, another Oomycota organism, to mandipropamid (Gisi et al. 2007). In our previous baseline sensitivity assessments, outliers with higher $\mathrm{EC}_{50}$ values for mycelial growth inhibition of $P$. syringae by fluopicolide and of $P$. citrophthora by ethaboxam were identified that were $\geq 23$-fold less sensitive than the most sensitive isolates of the respective species used in the study, and this was considered to possibly indicate a potential for selecting isolates with reduced sensitivity to these fungicides (Gray et al. 2018). Thus, as with any single-site mode of action fungicide, resistance management strategies should be followed from the onset of commercial use. Because two of the new fungicides each have the same registrant in the United States, the commercialization of premixtures will be facilitated.

In summary, our study demonstrated that the new Oomycota fungicides ethaboxam, fluopicolide, mandipropamid, and oxathiapiprolin provided highly effective control of Phytophthora root rot of citrus caused by $P$. nicotianae or $P$. citrophthora. The efficacy was generally better than for the previously available fungicides mefenoxam and potassium phosphite. The new compounds promoted the recovery of infected trees and enhanced fruit yield, with fluopicolide and oxathiapiprolin showing the most consistent increases in these measures. Based in part on our studies, fluopicolide recently received a federal and oxathiapiprolin a full registration for use on citrus, whereas registration for ethaboxam and mandipropamid has been requested.

\section{Acknowledgments}

We thank Kevin Nguyen, Daniel Chen, Gaju Ntwali, Dario Murillo, and Gio Gemelga for assisting in field fungicide applications, fruit harvesting, and root and soil samplings, as well as the nurseries for donating trees for the field studies.

\section{Literature Cited}

Adaskaveg, J. E., Förster, H., Hao, W., and Gray, M. 2017. Potassium phosphite resistance and new modes of action for managing Phytophthora diseases for citrus in the United States. Pages 205-210 in: Modern Fungicides and Antifungal Compounds. H. B. Deising, B. Fraaje, A. Mehl, E. C. Oerke, H. Sierotzky, and G. Stammler, eds. Vol. VIII. Deutsche Phytomedizinische Gesellschaft, Braunschweig.

Adaskaveg, J. E., Förster, H., and Mauk, P. A. 2014. Fungal diseases. Pages 307-326 in: Citrus Production Manual. L. Ferguson and E. E. GraftonCaldwell, eds. University of California Division of Agriculture and Natural Resources, Publ. 3539, Richmond, CA.

Bittner, R. J., and Mila, A. L. 2016. Effects of oxathiapiprolin on Phytophthora nicotianae, the causal agent of black shank of tobacco. Crop Prot. 81:57-64.

Blum, M., Boehler, M., Randall, E., Young, V., Csukai, M., Kraus, S., Moulin, F., Scalliet, G., Avrova, A. O., Whisson, S. C., and Fonne-Pfister, R. 2010. Mandipropamid targets the cellulose synthase-like PiCesA3 to inhibit cell wall biosynthesis in the oomycete plant pathogen, Phytophthora infestans. Mol. Plant Pathol. 11:227-243.

Cerkauskas, R. F., Ferguson, G., and MacNair, C. 2015. Management of Phytophthora blight (Phytophthora capsici) on vegetables in Ontario: Some greenhouse and field aspects. Can. J. Plant Pathol. 37:285-304.

Cohen, Y., and Samoucha, Y. 1984. Cross-resistance to 4 systemic fungicides in metalaxyl-resistant strains of Phytophthora infestans and Pseudoperonospora cubensis. Plant Dis. 68:137-139.

Cortright, B., Kirfman, G., and LeBlanc, M. 2016. Evaluating the efficacy of ethaboxam (V-10208) for control of Phytophthora capsici crown and root rot on fresh market peppers. (Abstr.) Phytopathology 106:S4.186-187.

Davidse, L., Looijen, D., Turkensteen, L., and Vanderwal, D. 1981. Occurrence of metalaxyl-resistant strains of Phytophthora infestans in Dutch potato fields. Neth. J. Plant Pathol. 87:65-68.

De Mendiburu, F. 2015. Agricolae: Statistical Procedures for Agricultural Research. R Package Version 1.2-3. http://CRAN.R-project.org/web/ packages/agricolae/index.html.

Erwin, D. C., and Ribeiro, O. K. 1996. Phytophthora Diseases Worldwide American Phytopathological Society, St. Paul, MN.

Ferguson, A. J., and Jeffers, S. N. 1999. Detecting multiple species of Phytophthora in container mixes from ornamental crop nurseries. Plant Dis. 83:1129-1136.

Ferguson, L., Sakovich, N., and Roose, M. 1990. California Citrus Rootstocks. University of California Division of Agriculture and Natural Resources, Publ. 21477, Oakland, CA.

Ferrin, D. M., and Kabashima, J. N. 1991. In vitro insensitivity to metalaxyl of isolates of Phytophthora citricola and P. parasitica from ornamental hosts in southern California. Plant Dis. 75:1041-1044.

Förster, H., Hao, W., and Adaskaveg, J. 2016. Reduced sensitivity to potassium phosphite in Phytophthora species and its implication for the management of Phytophthora brown rot of citrus. (Abstr.) Phytopathology 106:S4.198.

Foster, J. M., and Hausbeck, M. K. 2010. Managing Phytophthora crown and root rot in bell pepper using fungicides and host resistance. Plant Dis. 94:697-702.

Fox, J., and Weisberg, S. 2011. An R Companion to Applied Regression, 2nd Ed Sage Publishing, Thousand Oaks, CA. http://socserv.socsci.mcmaster.ca/jfox/ Books/Companion.

FRAC. 2018. FRAC Code List 2018: Fungicides sorted by mode of action (including FRAC Code numbering). Online publication. http://www.frac.info.

Gisi, U., and Cohen, Y. 1996. Resistance to phenylamide fungicides: A case study with Phytophthora infestans involving mating type and race structure. Annu. Rev. Phytopathol. 34:549-572.

Gisi, U., and Sierotzki, H. 2015. Oomycete fungicides: Phenylamides, quinone outside inhibitors, and carboxylic acid amides. Pages 145-174 in: Fungicide Resistance in Plant Pathogens: Principles and a Guide to Practical Management. H. Ishii and D. Hollomon, eds. Springer, New York, NY.

Gisi, U., Waldner, M., Kraus, N., Dubuis, P. H., and Sierotzki, H. 2007. Inheritance of resistance to carboxylic acid amide (CAA) fungicides in Plasmopara viticola. Plant Pathol. 56:199-208

Graham, J., Irey, M., and Taylor, J. 2011. Phytophthora damage to roots - a potential contributor to decline of HLB affected trees. Citrus Ind. May:20-23.

Graham, J. H. 1995. Root regeneration and tolerance of citrus rootstocks to root rot caused by Phytophthora nicotianae. Phytopathology 85:111-117.

Graham, J. H., Bright, D. B., and McCoy, C. W. 2003. Phytophthora - Diaprepes weevil complex: Phytophthora spp. relationship with citrus rootstocks. Plant Dis. 87:85-90. 
Graham, J. H., Johnson, E. G., Gottwald, T. R., and Irey, M. S. 2013. Presymptomatic fibrous root decline in citrus trees caused by Huanglongbing and potential interaction with Phytophthora spp. Plant Dis. 97:1195-1199.

Graham, J. H., and Menge, J. A. 1999. Root diseases. Pages 126-135 in: Citrus Health Management. L. W. Timmer and L. W. Duncan, eds. American Phytopathological Society, St. Paul, MN.

Gray, M., Hao, W., Förster, H., and Adaskaveg, J. 2018. Baseline sensitivities of new fungicides and their toxicity to selected life stages of Phytophthora species from citrus in California. Plant Dis. 102:734-742.

Hao, W., Förster, H., Miles, T. D., Martin, F. N., Browne, G., and Adaskaveg, J. E. 2016. A leaf litter and fruit brown rot life style of Phytophthora syringae in California citrus. (Abstr.) Phytopathology 106:S4.132.

Hao, W., Miles, T. D., Martin, F. N., Browne, G., Förster, H., and Adaskaveg, J. E. 2018. Temporal occurrence and niche preferences of Phytophthora species causing brown rot of citrus in the Central Valley of California. Phytopathology 108:384-391.

Holmes, K. A., and Benson, D. M. 1994. Evaluation of Phytophthora parasitica var. nicotianae for biocontrol of Phytophthora parasitica on Catharanthus roseus. Plant Dis. 78:193-199.

Hwang, J., and Benson, D. M. 2005. Identification, mefenoxam sensitivity, and compatibility type of Phytophthora spp. attacking floriculture crops in North Carolina. Plant Dis. 89:185-190.

Jackson, K. L., Yin, J., Csinos, A. S., and Ji, P. 2010. Fungicidal activity of fluopicolide for suppression of Phytophthora capsici on squash. Crop Prot. 29:1421-1427.

Ji, P., and Csinos, A. S. 2015. Effect of oxathiapiprolin on asexual life stages of Phytophthora capsici and disease development on vegetables. Ann. Appl. Biol. 166:229-235

Ji, P., Csinos, A. S., Hickman, L. L., and Hargett, U. 2014. Efficacy and application methods of oxathiapiprolin for management of black shank on tobacco. Plant Dis. 98:1551-1554.

Jiang, L., Wang, H., Xu, H., Qiao, K., Xia, X., and Wang, K. 2015. Transportation behaviour of fluopicolide and its control effect against Phytophthora capsici in greenhouse tomatoes after soil application. Pest Manag. Sci. 71:1008-1014.

Kim, D. S., Chun, S. J., Jeon, J. J., Lee, S. W., and Joe, G. H. 2004. Synthesis and fungicidal activity of ethaboxam against oomycetes. Pest Manag. Sci. 60: 1007-1012.

Lu, X. H., Hausbeck, M. K., Liu, X. L., and Hao, J. J. 2011. Wild type sensitivity and mutation analysis for resistance risk to fluopicolide in Phytophthora capsici. Plant Dis. 95:1535-1541.

Lutz, A., and Menge, J. A. 1986. Phytophthora root rot. Citrograph 72:33-39.

Matheron, M., and Mircetich, S. 1985. Pathogenicity and relative virulence of Phytophthora spp. from walnut and other plants to rootstocks of English walnut trees. Phytopathology 75:977-981.

Matkin, O. A., and Chandler, P. A. 1957. The U.C. type soil mixes. Pages 68-85 in: The U.C. System for Producing Healthy Container-Grown Plants. K. F. Baker, ed. University of California Division of Agriculture and Natural Resources, Manual 23, Berkeley, CA.
Meyer, M. D., and Hausbeck, M. K. 2013. Using soil-applied fungicides to manage Phytophthora crown and root rot on summer squash. Plant Dis. 97:107-112.

Miao, J., Dong, X., Lin, D., Wang, Q., Liu, P., Chen, F., Du, Y., and Liu, X. 2016 Activity of the novel fungicide oxathiapiprolin against plant-pathogenic oomycetes. Pest Manag. Sci. 72:1572-1577.

Miller, P. M. 1955. V-8 juice agar as a general-purpose medium for fungi and bacteria. Phytopathology 45:461-462.

Pasteris, R. J., Hanagan, M. A., Bisaha, J. J., Finkelstein, B. L., Hoffman, L. E., Gregory, V., Andreassi, J. L., Sweigard, J. A., Klyashchitsky, B. A., Henry, Y. T., and Berger, R. A. 2016. Discovery of oxathiapiprolin, a new oomycete fungicide that targets an oxysterol binding protein. Bioorg. Med. Chem. 24 354-361.

Patel, J. S., Costa de Novaes, M. I., and Zhang, S. 2015. Evaluation of the new compound oxathiapiprolin for control of downy mildew in basil. Plant Health Prog. 16:165-172.

R Core Team. 2015. R: A language and environment for statistical computing. R Foundation for Statistical Computing, Vienna, Austria. http://www.R-project. org/.

Ribeiro, O. K., Erwin, D. C., and Khan, R. A. 1978. New high-temperature Phytophthora pathogenic to roots of alfalfa. Phytopathology 68:155-161.

Roose, J. E. 2014. Rootstocks. Pages 307-326 in: Citrus Production Manual. L. Ferguson and E. E. Grafton-Cardwell, eds. University of California Agriculture and Natural Resources, Publ. 3539, Richmond, CA.

Saville, A., Graham, K., Grünwald, N. J., Myers, K., Fry, W. E., and Ristaino, J. B. 2015. Fungicide sensitivity of U.S. genotypes of Phytophthora infestans to six oomycete-targeted compounds. Plant Dis. 99:659-666.

Shin, J., Kim, J., Kim, H., Kang, B., Kim, K., Lee, J., and Kim, H. 2010. Efficacy of fluopicolide against Phytophthora capsici causing pepper Phytophthora blight. Plant Pathol. J. 26:367-371.

Stack, J., and Millar, R. 1985. Isolation and characterization of a metalaxylinsensitive isolate of Phytophthora megasperma f. sp. medicaginis. Phytopathology 75:1387-1392.

Timmer, L. W., Graham, J. H., and Zitko, S. E. 1998. Metalaxyl-resistant isolates of Phytophthora nicotianae: Occurrence, sensitivity, and competitive parasitic ability on citrus. Plant Dis. 82:254-261.

Toquin, V., Barja, F., Sirven, C., Gamet, S., Latorse, M. P., Zundel, J. L., Schmitt, F., and Beffa, R. 2006. A new mode of action for fluopicolide: modification of the cellular localization of a spectrin-like protein. Pflanzenschutz-Nachr. Bayer 59:171-184.

Uchida, M., Roberson, R. W., Chun, S.-J., and Kim, D.-S. 2005. In vivo effects of the fungicide ethaboxam on microtubule integrity in Phytophthora infestans. Pest Manag. Sci. 61:787-792.

Veena, S. S., Anandaraj, M., and Sarma, Y. R. 2010. Variability in the sensitivity of Phytophthora capsici isolates to potassium phosphonate. Indian Phytopathol. 63:71-75.

Wilkinson, C. J., Shearer, B. L., Jackson, T. J., and Hardy, G. E. S. 2001. Variation in sensitivity of Western Australian isolates of Phytophthora cinnamomi to phosphite in vitro. Plant Pathol. 50:83-89. 